\title{
Errata: Second harmonic generation imaging as a potential tool for staging pregnancy and predicting preterm birth
}

\section{Meredith L. Akins}

University of Texas Southwestern Medical Center

Department of Obstetrics and Gynecology

5323 Harry Hines Boulevard

Dallas, Texas 75390

\section{Katherine Luby-Phelps}

University of Texas Southwestern Medical Center

Department of Cell Biology

5323 Harry Hines Boulevard

Dallas, Texas 75390

\section{Mala Mahendroo}

University of Texas Southwestern Medical Center Department of Obstetrics and Gynecology

5323 Harry Hines Boulevard

Dallas, Texas 75390

[DOI: $10.1117 / 1.3459021]$

This article [J. Biomed. Opt. 15, 026020 (2010)] was originally published online on 28 April 2010 with an omission in the acknowledgments. The following sentence has been added to the text:

This work was supported in part by the National Institutes of Health Grant R01HD043154 and The Hartwell Foundation (to M.M.).

All versions of the article were corrected on 5 May 2010. 